\title{
INTERPARTY CO-OPERATION AND URUGUAY'S 1952 CONSTITUTION*
}

\author{
Philip B. TAYlor, JR. \\ University of Michigan
}

$\mathrm{U}$ RUGUAY IS generally thought to be the most democratic of the Latin American nations. There one enjoys the same personal and property freedoms that generally obtain in the United States, and the effect of these is heightened by the fact that its population is about three million. But Uruguay was not always so democratic. The civil peace which is the primary cause of the well-being and contentment of the people was gained after three-quarters of a century of struggle. Although Uruguay became independent in 1828, it was not until 1904 that clear predominance of national over sectional power was achieved.

Like many other Latin American nations, Uruguay adopted a first constitution which permitted a continuance of governmental control by representatives of groups similar to those which had been in control during the colonial period. An indirectly elected president who possessed great powers under the Spanish-inherited predilection for highly personalist and absolutist government, was virtually a reincarnation of the absolute monarch. ${ }^{1}$ As such, the office became the goal of many who did not hesitate to employ violence in their pursuit of it. Latin America did not really go though a "revolution" in the early nineteenth century; as one eminent student of the area has said, it "seceded" from the Spanish Empire. ${ }^{2}$

Under these circumstances, political parties became personal organizations little disposed to peaceful rotation in office. Civil war became a substitute for elections. The continual intervention of Argentina and Brazil on behalf of one or the other of the principal Uruguayan "political parties" perpetuated an already anarchic condition. ${ }^{3}$ Thus supported, the parties possessed relatively equal military force.

In order to achieve peace, it became the custom, beginning in 1851, to draw treaties or pacts between the principal contenders for power. Thus, in October of that year, a treaty was concluded between the Blancos,

\footnotetext{
* Research for this paper was made possible in part by a grant from the Horace H. Rackham Foundation.

1 It is patadoxically true that the hyperindividualist Latin American bas allowed himself to be ensnared into the acceptance of an absolute leader literally hundreds of times in the history of the area. A book title by Ernest Hambloch states the matter rather well, and in terms of nearly universal applicability: "His Majesty, the President of Brazil." This phenomenon is thoughtfully discussed by many writers, among the best being Lionel Cecil Jane in his Liberty and Despotism in Spanish America (Oxford: England, 1929); and Sol Tax in "The Problem of Democracy in Middle America," American Sociological Review, X (April, 1945).

2 Professor Irving Leonard of the University of Michigan, to the writer.

${ }^{3}$ Pablo Blanco Acevedo, Estudios Constitucionales (Montevideo, 1939), 49-61; J. E. Pivel Devoto, Historia de la República Oriental del Uruguay (1830-1930) (Montevideo, 1945), 17-121; José G. Antuña, La junta de gobierno y el partido colorado (Montevideo, 1913), 20.
} 
headed by General Manuel Oribe, and the Colorados, led by General Fructuoso Rivera. ${ }^{4}$ But while the 1851 agreement was, in many respects, a treaty of peace, a second agreement in 1872, following another civil war, showed those characteristics which have caused some Uruguayans to liken the situation to the Missouri compromise in the United States. The Blancos won a military victory over the government, controlled by the Colorados, and, aided by the mediation of the Argentine consul in Montevideo, were granted hegemony in four of the nineteen Departments into which the country is divided. 5 In 1897, following another period of chaos, the government was forced to broaden the grant of control to six Departments. ${ }^{6}$

But the territorial apportionments of 1872 and 1897 are only symptomatic of deeper difficulties. The provisions of the pacts suggest the nature of some of these other problems. However powerful they may have been on the battlefield, the Blancos have never been able, under whatever election laws, to elect a candidate to the presidency; they have not controlled that office since 1868 . They have been concerned, therefore, with placing party representatives in other national, and in local offices. The settlements of 1872 and 1897 contained provisions regarding election of members of the General Assembly (the national legislature) which would permit more Blancos to be elected than under the previous regulations. The later pact also provided that these reforms should be extended to the election of members of the partially autonomous Departmental "Administrative and Economic Juntas." 7

The Blancos were concerned with the enforcement of national laws within those territories they controlled. Because Uruguay is a unitary

\footnotetext{
4 Oribe and the Argentine forces of Juan Manuel Rosas fought Rivera, backed by the Brazilians, for twelve years (1839-1851) in the "Guerra Grande," which was featured by the siege of Montevideo and intervention by the British and French fleets. As the end of the period approached, an alliance against Rosas developed in Argentina under Justo José Urquiza. Brazil supported this alliance, and it became clear that Oribe would have to make his peace with Rivera or be wiped out. He did so, and a triple alliance defeated Rosas at Monte Caseros, February 3, 1852. Pivel Devoto, op. cit., 191-199; Eduardo Acevedo, Obras Históricas (Montevideo, 1933), III, 351-356.

5 Eduardo Acevedo, op. cit., IV, 647-649; J. E. Pivel Devoto, Historia de los partidos políticos en el Uruguay (Años 1865-1897)" (Montevideo, 1943), 46-55, 106. The "Peace of April" received great public acclaim, and became the subject of a monument erected the following year at the place of signing, the town of San José. See also Juan Andrés Ramirez, Sinopsis de la evolución institucional (Montevideo, 1949), 106-107.

- Eduardo Acevedo, op. cit., VI, 16-17. At pp. 116-117, the writer notes that the settlement was popularly received, although it was a bitter pill for the government, since the president had been assassinated received, although it was a bitter pill for the government, since the president had been assassinated
after initial government refusal to negotiate. The settlement's popularity was attested by a public after initial government refusal to negotiate. The settlement's popul
demonstration of nearly 40,000 people in the streets of Montevideo.

Elsewhere (ibid, 139), Acevedo notes that Uruguay endured forty-one revolutions in its first seventy-one years of political independence.

i Until the constitutional reform of 1934, Senators were elected by electoral colleges in the individual Departments. The Blancos at least were assured Senators from those Departments which they Departments. The Blancos at least were assured Senators from those Departments which they
controlled. Further, the 1897 agreement provided that a certain minimum percentage of seats in controlled. Further, the 1897 agreement provided that a certain minimum percentage of seats in
the Chamber of Representatives should be assigned to the minority party. In 1873 proportional representation, as a solution to the problem of achieving adequate minority representation, was first suggested by Professor Justino E. Jimenéz de Aréchaga of the University of Montevideo Law School. It was not accepted fully until 1918 .

The juridical status of the 1897 settement is evidenced by its incorporation in the semiofficial collection of statutes, Colección legislation de la República Oriental del Uruguay. See Colección, XX, 272-277, for the text of the treaty, and ibid., XXI, 96.114 and 328-345, for the two laws resulting from the agreement.

The pacts of 1851,1872 , and 1897 also included cash settlements to the Blanco partisans, to be paid on their disbandment, and guaranteed that the government would take no steps to deprive them of their civil or legal rights.
} 
nation, this enforcement was by an officer appointed by the central government. The Blancos received the right to nominate these Jefes Politicos, Departmental political chiefs, in their six Departments. These Departments can be characterized loosely as those in which stock raising was and is of great economic importance, and in which the large ranch is a typical form of land tenure. ${ }^{8}$ The settlements can thus be interpreted as modi vivendi, compromises of convenience for the preservation of the social and economic integrity of a group which felt itself bound to suffer under majoritarian rule. The group tended then, and tends in 1954, to view itself as the repository of values no longer held by the majority. The position is stated succinctly by one Uruguayan writer:

A Blanco congress, convened after 1904, in order to adopt policies and attitudes, recognizes and declares, with pride in itself and scorn for the opposition, that the nacionalistas represent the gentlemanly, pure-blooded, and patrician tradition of Uruguay, while the colorados are the party of the immigrants."

The allocation of territorial control came to an end after the civil war of $1904,{ }^{10}$ in which a military victory was won by the government. Within a short time, the carefully erected legal basis for a split nation came to an end. Uruguay's political history since that time has been more conventional. But the institution of the political pact remains.

The pact of the parties has been used both for and against constitutional government. Some pacts have been mere working agreements whereby laws and constitutional amendments have been written by mutual consent and compromise. But others have created situations in which two principal holders of power combine to exclude from participation in government all with whom there is disagreement. The pact of the parties, on occasion, has been employed constitutionally to ratify naked power grabs. In order to undo its effects, domestic peace has been broken twice since 1904 by coups. ${ }^{11}$

\footnotetext{
${ }^{8}$ In the negotiations of 1897, the Blancos bid initially for the control of eight Departments. The statistics in the table below are from Russell Fitzgibbon, Uruguay, Portrait of a Democracy (New Brunswick, 1954), 55. Professor Fitzgibbon has developed these data from official Uruguayan estimates of 1944. Extrapolation of official estimates indicates that Uruguay's total population in 1897 was perhaps 700,000 , ox $30 \%$ of that of 1944 .

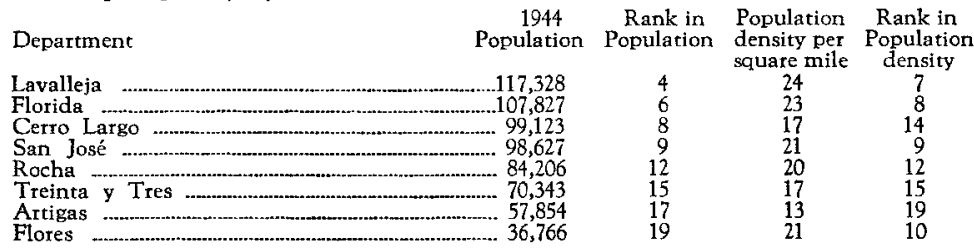

${ }^{9}$ Alberto Zum Felde, Evolución histórica del Uruguay (3rd ed.; Montevideo, 1945), 224-225. Italics are Zum Felde's.

20 The blame for precipitating the conflict has never been definitively assigned, but it is safe to assume that war certainly would have come. The years $1897-1904$ witnessed, at best, what was anly an armed truce. See Pivel Devoto, História de la R. O. del Uruguay, 538-542; Justino Zavala Múniz, Batlle, heroe civil (Mexico, 1945), 166-171; Eduardo Acevedo, op. cit., VI, 259-279.

${ }^{11}$ See this author, "The Uruguayan Coup d'Etat of 1933," The Hispanic American Historical Review. XXXII, 301.320 (August, 1952).
} 
If the pact of the parties were left with this condemnation, it could be assumed that governmental power has frequently been seized and controlled by skulduggery, and that the nation has not benefited very much. But this would be a misstatement. Pacts have allowed the Blancos, as well as other opposition groups, sufficient political freedom and entrée into bureaucratic, legislative, and, on occasion, executive positions, to enable these groups to support the government. From the vantage point of Latin American history, we can see that this is a feat of no little importance. It has permitted the development of extensive personal and group freedoms. It has even tended to produce a Latin American anomaly: a government in which the Executive Power is not necessarily predominant. ${ }^{12}$

II

The constitution of 1952 incorporates few principles that are new to Uruguay, although its length makes it at least the equal of the justly famed Mexican constitution of 1917. The plural Executive or Colegiado, the National Council of Government, has evoked interest and curiosity among students of government. The creation of this council is, in fact, the principal reason for this second revision of the document of $1934 .{ }^{13}$ Its existence is the result of another pact of the parties.

The Colegiado became a serious political issue in 1913. José Batlle y Ordóñez became impressed with the idea of a plural executive as a solution to the perennial Latin American problem of caudillismo ("leaderism"). It is by no means clear whether he proposed a collegiate because he thought it would frustrate the institution of caudillismo, or because he thought it would be a place to which a caudillo would gravitate. He submitted the subject to public debate in a newspaper interview; it remains a live issue today. ${ }^{14}$ One writer on the debate has written, "The original sin of the project was its paternity," 15 for Batlle was truly one of the last of Uruguay's

\footnotetext{
12 Even with the unipersonal presidency of the 1942 constitution, it was by no means clear that the president would be the unchallenged boss of the nation. See this author, The Executive Power in Uruguay (Berkeley, 1951), 18-25. The 1952 document seems to weaken the Executive Power in a number of ways. This will increase the contrast between Uruguay on the one hand and Mexico number of ways. This will increase the contrast between Uruguay on the one hand and Mexico
and Argentina on the other. Regarding this aspect of these two nations see Frank Tannenbaum, and Argentina on the other. Regarding this aspect of these two nations see Frank Tannenbaum,
Mexico, the Struggle for Peace and Bread (New York, 1950), 83-91; and George Blanksten, Peron's Argentina (Chicago, 1953), 111-157.

13 The constitution of 1942 is viewed by some writers as only a revision of the 1934 document, and the 1952 constitution as a revision of the 1942 version. To a large extent this is true. See Russell H. Fitzgibbon and others (translators), The Constitutions of the Americas (Chicago, 1948), 713-714.

14 Batlle's statement was made in El Dia (Montevideo) of March 4, 1913. But many writers argue that he did not originate it. José Luciano Martínez, in Gabriel Terra, el hombre, el político, el gobernante (Montevideo, 1937), II, 178, states that Batlle's inspiration came from a draft constitution written in 1812 for the United Provinces of the Río Plata (the predecessor of the present Argentina). Luciano quotes Batle as saying, ". . . with minor changes... it could be used Argentina). "I

The matter had been discussed previously by two other persons in Uruguay. Martin Aguirre proposed a colegial executive in the Ateneo of Montevideo in 1903. See Juan E. Pivel Devoto Uruguay Independiente (Barcelona, 1949), 622. José Espalter, a member of the General Assembly, discussed the idea in a pamphlet in 1904. See Espalter, Discursos Parlementarios (Montevideo, 1942), VIII, 427-429.

16 Antuña, op. cit., 33.
} 
great caudillos. It created schisms within the Colorado party that have never fully healed.

A constitutional convention met in 1917. Batlle's supporters found themselves in a minority position, although they still controlled the General Assembly. For a time there was a genuine fear of civil war. But the middle-of-the-road newspaper Diario del Plata proposed a pact between the major parties, and this occurred. ${ }^{16}$ The result was a queerly hybridized Executive, really satisfactory to few. ${ }^{17}$ Responsibility was so decentralized that, when economic crisis developed in 1932 and 1933, the government was helpless to marshal its forces to meet it. ${ }^{18}$ Factionalism developed around two prominent party leaders, one of them the president, Gabriel Terra. The other was the highly ambitious Blanco leader, Luis Alberto de Herrera. It became apparent that the two had lost their control of a majority of the legislature. A pact concerning control of the national bureaucracy, which had been formalized in law in 1931, came to be used against Terra's government. ${ }^{19}$ Ultimately, Terra overthrew the government by force, and he and Herrera made a pact of their own, one more reprehensible than anything that had preceded it. ${ }^{20}$

The 1934 constitution allowed a return to the single Executive officer. But the price was a Senate equally divided between the two groups backing Herrera and Terra. ${ }^{21}$ Terra remained as president, and was able to pervert the constitutional structure to his own purpose. Ultimately, this action provoked its own reaction, and Terra's successor, Alfredo Baldomir, destroyed the government by his coup of February, 1942.

There followed a period of nearly a decade during which the pact of the parties was employed in ways which would be more understandable to United States politicians. The two major parties collaborated at times,

${ }^{16}$ Batlle's supporters had ridiculed the opposition during the campaign. For the first time in Uruguayan history, the vote was secter. Many former nonvoters turned out. See Ramirez, op. cit., 90-92; Zavala Múniz, op. cit., 215-219; Roberto Giudici, Batlle y el Batllismo (Montevideo, 1928), $493-494$. The results of the voting are found in Eduardo Acevedo, op. cit., VII, 8.

${ }_{17}$ A popularly elected President of the Republic served a four year term; he controlled foreign affairs the armed services, and the police. There was also a National Council of Administration of nine members, elected by thirds each two years; the Council controlled other governmental functions, including the budget. The Constitution of 1918, arts. 70-104. The debates in the constitutional convertion of 1917 concerning the Executive are in Urugusy, Diario de sesiones de la Honorable Convención Nacional Constituente de la República Oriental del Uruguay (Monte. de la Honorable Convencion
video, 1917), III, 165-168ff.

${ }^{18}$ See Aquiles Espalter, Algunos aspectos de la organización del Poder Ejecutivo en la constitución de 1934, y el régimen del ministerio de las mayorias (Montevideo, 1937), 21-25, for an attack on th capacity of the Colegiado.

Economic trends during the period are discussed in Eduardo Acevedo, op. cit., Vil, 303-362, 447-550; and Simon Hanson, Utopia in Uruguay (New York, 1938), 229; and Eduardo Acevedo Alvarez, La economía y las finanzas públicas despues del 31 de Marzo (Montevideo, 1937).

19 The pact was contained in Law 8765, October 15, 1931 (1931 Registro de leyes de la Republica Oriental del Uruguay, 577), which Terra later dubbed el Pacto del Chinchulin (literally, the pact of the pork barrel). The law originally had been passed with Terra's approval and support, and he did not turn against it until it began to be used against him by his opponents. See Gustavo Gallinal, El Urugtay hacia la dictadura (Montevideo, 1938), 187-221, for a general discussion of this event.

so This phase of Uruguayan political history is discussed in this author's arricle, "The Uruguayan Coup d'Etat of 1933," op. cit.

${ }^{21}$ Art. 86 of the document provided that 15 members of the Senate should be assigned to each of the two leading parties in a Senatorial election. Terra and Herrera were helped to get control of the General Assembly by the electoral abstention of their opponents. 
but seldom to the exclusion of the numerous minor groups which exist by virtue of the use of proportional representation in national and local elections. The Batllista faction of the Colorado party continued to press for the readoption of the plural Executive, although this was not always uppermost in its platform. The general elections of 1942, 1946, and 1950 were disappointing to the Blancos, because they showed considerable continuing strength on the part of the Colorados. ${ }^{22}$ The Batllistas disparaged proportional representation because they realized that a singlemember district system would give more positive control of the legislature to them and to the Colorado party. ${ }^{23}$

Finally, Herrera and the president, now Andrés Martinez Trueba, a Batllista, agreed in July, 1951, to the establishment of a nine-man Executive body entitled the National Council of Government. ${ }^{24}$ Its membership is renewed every four years; six seats are apportioned to the "mostvoted" party. Direct re-election of Councilors is forbidden. They jointly appoint nine ministers who carry on the administrative work of government. The presidency of the Council rotates annually among members of the majority party, and the occupant of the office is the formal chief of the State. ${ }^{25}$ The new constitution contains other unique provisions, including a serious effort to establish a civil service classification and tenure system, greater local self-government, and assured fiscal regularity. ${ }^{26}$

\section{III}

It is difficult to see that the new Colegiado will serve any useful purpose. Under the 1942 constitution's articles 174-176, it had been implied clearly that the president could admit his ministers to virtually equal responsibility and authority in the determination and conduct of public policy; thus could have been formed an effective colegiate. Whether or not this was done depended on the personality of the individual president. ${ }^{2 \pi}$ The new document merely transfers the powers previously entrusted to the

22

VOTES CAST IN PRESIDENTIAL ELECTIONS, AND PERCENTAGES RECEIVED BY PRINCIPAL PARTIES

\begin{tabular}{lccccc} 
& & \multicolumn{3}{c}{ PERCENTaEs } \\
Year & Total Vote Cast & Colorado & Nacional (Blanco) & Nacional Indep. Catholic \\
1938 & 327,205 & 61.3 & 32.1 & abstain & abstain \\
1942 & 574,703 & 57.1 & 22.8 & 11.6 & 4.2 \\
1946 & 665,136 & 47.8 & 32.0 & 9.8 & 5.4 \\
1950 & 823,829 & 52.6 & 30.9 & 7.6 & 4.3
\end{tabular}

Sources: Julio Fabregat, Elecciones Uruguayas (2d ed.; Montevideo, 1948), IX, 8; and Fabregat, Elecciones Uruguayas (3d ed.; Montevideo, 1953), 6-8.

23 An interpellation of the Subsecretary of the Ministry of the Interior in the Chamber of Representatives, on August 20-21, 1948, produced a review of the arguments in this matter. See Uruguay, 475 Diario de la Cámera de Representantes de la República Oriental del Uruguay (Montevideo, 1948), 318 ff.

24 For a summarization of the terms of the agreement, see George Pendle, Uruguay, South America's First Welfare State (London, 1952), 24-25. Also, Milton I. Vanger, "Uruguay Introduces Government by Committee," The American Political Science Review, XLVIII (June, 1954), 502-509.

${ }^{25}$ Constitution of 1952, arts. 149-151, 153, 158, 167, 174.

${ }^{26}$ Ibid., arts. 58-63, 262-273, and 208-213 respectively. Uruguay's leading constitutional commentator, Justino Jiménez de Aréchaga, is somewhat critical of many of these provisions, however. See his fout-volume work, La Constitución de 1952 (Montevideo, 1953).

27 This author, The Executive Power in Uruguay, op. cit., 21-22. 
president to nine men, incapable of giving policy directives individually. ${ }^{28}$ It would appear that Uruguay has re-established an Executive whose capacity for rapid and effective action in a crisis is open to some question. One challenge to the government has occurred so far, a general strike. The somewhat conservative Colegiado met this by unanimous action. The strike was illegal, in part, because it began among government employees, who are forbidden to strike. While Uruguayans who support the Colegiado feel that this action sets a precedent for the future, its opponents doubt this. Further, the collapse in 1933 of the previous colegial government occurred because of inability to act in a positive fashion; negative action, such as strikebreaking, is frequently easier to accomplish. ${ }^{29}$

Opponents of the Colegiado claim that it is not supported wholeheartedly by the people. They question the significance of the plebiscite, in which a scant 9 per cent of the total population of the nation ratified the new constitution. ${ }^{30}$ They contend that the plural membership and the secrecy in the making of policy decisions are conducive to irresponsibility. Critics of the emergency measures of September, 1952, have stated that these would not have been made by a single, obviously responsible president. $^{31}$

Other opponents of the new system argue that Uruguay has once again fallen victim to the pact of the parties. ${ }^{32}$ Herrera and his party, who were excluded from participation in the Executive by the 1934 constitution, are readmitted to participation. So long as the two major party groups and leaders co-operate, the government will probably continue to operate without difficulty. Party discipline is sufficiently strong to assure that legislative members will generally do the bidding of the respective

\footnotetext{
25 Art. 167, par. 2 of the new constitution states, "The National Councillors may not, individually, give orders of any kind." Decisions are, in fact, being made by joint decision of the colegiate, and with joint responsibility observed.

20 The preceding government, that of Luis Batlle Berres, had been sympathetic to labor. It has been alleged that his supporters encouraged strikes, illegal or not, in order to force the government bodies which control wage rates in a number of enterprises to approve raises. The supporters of this line of reasoning state that the 10,000 transit workers in the municipally owned streetcar and bus system of Montevideo expected such suppport when they struck in September, 1952. It was bus system of Montevideo expected such suppport when

The Colegiado justified its action against the strike by noting the arrival of an Argentine agitator in a shoe factory which was on sympathy strike; a state of emergency was declared under art. 168, par. 17 of the constitution. The movement was abandoned. New York Times, September 12-23 and December 18, 1952; Visión, October 3 and November 28, 1952.

30 $1,168,876$ were registered to vote. Article 281 (B) of the 1942 constitution provided that amending plebiscites required at least a $35 \%$ turnout of this number $(408,872)$. In fact, $36.7 \%$ did vote $(429,760)$, and $54.0 \%$ of the votes favored the new document $(232,076)$. Thus, $19.8 \%$ of the tegis tered voters voted for the new constitution, a figure equal to not more than $9 \%$ of the total population. Fabregat (3rd ed.), op. cit., 1-2; and New York Times, December 17, 1951.

The campaign prior to the plebiscite had been heated, with the Batllista wing of the Colorado parry (the dominant wing) badly split, and with students at the University striking in protest against its provisions conceming the National University. Labor union opposition, led by former against its provisions conceming the National University. Labot union opposition, led by former
president Batlle Berres, produced a majority against the ratification in Montevideo of 33,624 . All president Batle Berres, Froduced a majority against the ratification in Montevideo of 33,624 . All
other Departments returned a favorable majority, however. See Uruguay, Electoral Court, Circular No. 3010 (Montevideo, January 17, 1952), and New York Times, loc. cit.

31 Visión, October 3, 1952.

32 See the Washingtor Post, January 5, 1952, for a letter from a Montevideo resident criticizing the new constitution.
} 
party directorates. ${ }^{33}$ But Herrera is in his 80 's, and his retirement is hopefully anticipated (by many of his own followers!) in the near future. Will the successors of Herrera and Martínez Trueba be able to work together in what could well be a delicately balanced situation? It was, after all, the failure of the parties to work together in 1933 in the face of crisis and heightened personalist tensions that brought on the downfall of the previous Colegiado. Former president Luis Batlle Berres, who aspires to continuance in power, has made clear his great dissatisfaction with the Colegiado. He argues that, while the Batllistas have long favored a "pluripersonal" executive, they have not favored a body composed of members of many parties. His opposition, expressed in the campaign preceding the plebiscite in 1951 , has become more open in preparation for the general elections of November 28, 1954. ${ }^{34}$ It seems clear that there will be two leading issues before the voters in the forthcoming campaign: the retention of the presently organized Colegiado, and the position of Batlle Berres himself.

In preparation for the January, 1954, Colorado party convention, Batlle Berres made his own position clear. His opponents within the Batllista wing, led by César Batlle Pacheco, the late Batlle y Ordóñez' son, advocated a slate of executive candidates composed of supporters of both wings. Batlle Berres urged the convention to designate two slates, each to be composed entirely of supporters of each of the two men. In effect, he is playing for five seats in the Colegiado rather than the two or three he would otherwise get. The convention followed Batlle Pacheco, but Batlle Berres remains determined. ${ }^{35}$ It is improbable that under present circumstances he could establish himself as a dictator, but his predilection for power seems apparent from the record. The present balance of proand anti-colegial forces would probably preclude an immediate effort on his part to revise the constitution further. But the voters will have a clear choice before them.

In the short run, it seems unlikely that Uruguay will feel the high pitch of economic pressures which toppled the colegiate of 1918-1933. But the force of a new caudillo or, equally likely, a new depression could upset the balance. Uruguay depends heavily for its economic well-being on international trade, the bulk of its exports falling in the categories of meat

\footnotetext{
33 Discipline within the highly-institutionalized Colorado party, especially in its Batllista wing, has enabled it to operate effectively on many occasions in the past. Hertera, the Blanco leader, exercises as positive a personal leadership over his followers as almost any Latin American caudillo. Personal observation, Fitzgibbon (Uruguay, Portrait. . . ), op. cit., and Vanger, op. cit., concur in this respect.

34 Visión, May 13, June 10, and October 3, 1952; November 13, 1953.

35 Visión, November 13, 1953, and El Bien Público (Montevideo, July 27, 1954).
} 
and grain. Although its inflation, even by United States standards, is not serious, strikes and continued demands for wage raises cause concern. ${ }^{36}$

A more serious criticism can be made of the pact of 1951. The Pacto del Chinchulín of 1931 established in law the principle that bureaucratic employment should be apportioned among all the parties in rough proportion to their strength in the preceding election. This was not a new principle in Uruguayan civil service practice. ${ }^{37}$ It would seem, on the basis of interviews by the writer with Uruguayans of opposing parties, that this has become a thing of the past, and that nearly all new government employees are hired only from the two major parties.

Nine men now perform the work of one. They do not actually head the executive departments of the government; for ministers, appointed in rough proportion to the apportionment of colegiate seats among the various parties, head these departments as formerly. On the surface it appears decidedly easier to censure the ministers. ${ }^{38}$ But the ministers now have nine bosses; this situation seems unenviable. Further, eighteen persons are concerned with executive policy, rather than the former ten. This situation also seems to admit of confusion.

Proportional representation has been a feature of the electoral system since its adoption for the Chamber of Representatives in 1918. ${ }^{39}$ Subsequent developments have extended its use. A Montevideo voter will choose from among fifty or so lists of legislative candidates at the quadrennial election. But within a few days, there will be a return to the basic pattern of three principal parties or lemas, with the Colorado party containing three fractions or sub-lemas. This writer theorizes that this has taken place in the past because of the popular election of the president. A nation-wide political machine has been necessary to assure that both the election and a working legislative majority would accrue to a single individual. In

\footnotetext{
36 Visión, May 13 and October 3, 1952. Also, Chase National Bank of New York, Latin American Business Highlights, June, 1952, pp. 26-27; June, 1953, pp. 22-23; and December, 1953, p. 23. Business Highlights, June, 1952, pp. 26-27; June, 1953, pp. 22-23; and December, 1953, p. 23.
The New York Times, January 6, 1954, p. 49, presents the most up-to-date picture of the numerous inflationary pressures, some of them induced by the administration of Batle Berres. Visión, May 13, 1952, quotes "an Uruguayan diplomat": "In Batllismo there was a fear that one fine day there would appear a man, that he would make himself president; and, with the power in his hands, the Batlistas would be forgotten."

${ }^{37}$ By way of example, the Electoral Court is a quasi-judicial body which regulates all Uruguayan elections, It supervises several hundred employees. Within three weeks of its establishment in 1924, the Court determined that its employees would be hired on the basis outlined above. See Jiménez de Aréchaga, La Constitución Nacional (Montevideo, 1949), X, 124-125; see also Julio T. Fabregat, Los Partidos políticos en la legislación uruguaya (Montevideo, 1949), 135-139.

38 Arts. $136-144$ of the 1942 constitution dealt with legislative censure of the ministers. Censure was so difficult, mechanically, that it never occurred; rather, in a number of instances, ministers resigned after vigorous interpellation resulted in what was known as "implied censure." See this author, "The Executive Power in Uruguay," op. cit., 39-40.

Arts. $147-150$ of the 1952 constitution also deal with censure. Eirher chamber of the General Assembly may propose it, and a joint session's absolute majority vote suffices to force immediate ministerial resignation.

${ }^{39} 1918$ constitution, art. 19, stated that this Chamber would be elected as a subsequent electoral law would direct. 'Transitory art. "C' " provided that the law of September 1, 1915 (1915 Registro. would direct. Transitory art. "C'" provided that the law of September 1, 1915 (1915 Registro
de leyes. . del Uruguay $630-643$ ) would be applicable in the interim. Art. 50 of the law provided de leyes distribution of seats in the constitutional convention proportional to the vote count for the for distribution of seats in the constitutional convention proportional to the yote count for the
various parties. It was not until the passage of the Election Law of January 16, 1925, ibid., 27-59, that a general revision of the election law was accomplished. See Jiménez de Aréchaga, op. cit., III, 85 ff.
} 
short, the popular election of the president has had a "polarizing" effect on the parties. It would seem that the election of the Colegiado will produce similar results. The assignment of six seats to the victorious party will assure lively party organizations, and the assignment of three seats to the next party should assure an effective opposition party. The theory seems borne out in the circumstances of the present campaign, for, while there is intense competition for power by Batlle Berres, there is as yet no indication that he proposes to bolt the Batllista wing of the Colorado party. The Blancos, too, are effective. In fact, it may logically be conjectured that they are the world's longest-lived opposition party: eighty-six years in that position with only scant fruits of victory! It is worthy of note that both parties support the constitutional order in general, and accept the extensive government economic activity which stamps Uruguay as a thoroughgoing socialist nation.

The re-creation of the Colegiado has re-admitted the Blancos to participation in the executive's policy-making and executing role. In view of this party's long-time electoral weakness, this is perhaps desirable. A slight impairment of executive efficiency, for the moment, may well be overbalanced by the sense of broadened popular participation in policy decisions. Eighty per cent of the electorate are now represented by the officers who make policy decisions. This is not bad, especially in view of Latin America's dictator-haunted past. There seems some justification for the comment, "With the colegial system, a deathblow has been delivered to demagogy." 40 Yet it seems undeniable that demagogy will be an issue of some importance in the coming election.

Beyond this, another point is worth considering. Constitutions presuming to be democratic are ineffective unless, in some way, they receive philosophical and emotional support from the governed. For too long, Latin America labored under forms of government copied unthinkingly from other nations. The art of government demands thoughtful experimentation and development to reach its most effective expression, and the Colegiado may well be considered Uruguay's contribution to such development. Superficially, a record of four constitutional reforms in thirty-four years does not indicate stability. But the new change indicates a sincere effort to reach a degree of political peace and real national unity. The pact of the parties has contributed materially to this end. In a very real sense, Uruguayans view their nation as a laboratory.

40 Visión, May 13, 1952. 